IZA DP No. 7119

Children, Spousal Love, and Happiness: An Economic Analysis

Shoshana Grossbard

Sankar Mukhopadhyay

December 2012 


\title{
Children, Spousal Love, and Happiness: An Economic Analysis
}

\author{
Shoshana Grossbard \\ San Diego State University, \\ University of Zaragoza and IZA \\ Sankar Mukhopadhyay \\ University of Nevada, Reno
}

Discussion Paper No. 7119

December 2012

\author{
IZA \\ P.O. Box 7240 \\ 53072 Bonn \\ Germany \\ Phone: +49-228-3894-0 \\ Fax: +49-228-3894-180 \\ E-mail: iza@iza.org
}

Any opinions expressed here are those of the author(s) and not those of IZA. Research published in this series may include views on policy, but the institute itself takes no institutional policy positions. The IZA research network is committed to the IZA Guiding Principles of Research Integrity.

The Institute for the Study of Labor (IZA) in Bonn is a local and virtual international research center and a place of communication between science, politics and business. IZA is an independent nonprofit organization supported by Deutsche Post Foundation. The center is associated with the University of Bonn and offers a stimulating research environment through its international network, workshops and conferences, data service, project support, research visits and doctoral program. IZA engages in (i) original and internationally competitive research in all fields of labor economics, (ii) development of policy concepts, and (iii) dissemination of research results and concepts to the interested public.

IZA Discussion Papers often represent preliminary work and are circulated to encourage discussion. Citation of such a paper should account for its provisional character. A revised version may be available directly from the author. 
IZA Discussion Paper No. 7119

December 2012

\section{ABSTRACT \\ Children, Spousal Love, and Happiness: An Economic Analysis}

In this paper we examine how children affect happiness and relationships within a family by analyzing two unique questions in the National Longitudinal Study of Youth's 1997 cohort. We find that (a) presence of children is associated with a loss of spousal love; (b) loss of spousal love is associated with loss of overall happiness; but (c) presence of children is not associated with significant loss of overall happiness. If children reduce feelings of being loved by the spouse but do not reduce reported happiness even though spousal love induces happiness, then it must be the case that children contribute to parental happiness by providing other benefits. After ruling out some competing compensation mechanisms we infer that loss of spousal love is compensated with altruistic feelings towards children.

JEL Classification: J13, D10

Keywords: children, happiness, emotions, marriage, religion

Corresponding author:

Shoshana Grossbard

Department of Economics

San Diego State University

San Diego, CA 92182-4485

USA

E-mail:shosh@mail.sdsu.edu 


\section{Introduction}

In the tradition of the Columbia School of Household Economics (i.e. the New Home Economics) started by Becker (1960) and Mincer (1962), economists such as Willis (1974) have modeled fertility in terms of households choosing their preferred number of children by comparing costs and benefits. These costs include opportunity costs that have been estimated in terms of foregone wages (Becker 1960, Mincer 1963, Waldfogel 1998, Bryan and Sevilla-Sanz 2011, Giannelli et al. 2012), time in home production (Gustafson and Kjulin 1994, Gutierez-Domenech 2010), and foregone leisure (Craig and Bittman 2008, Ekert-Jaffe and Grossbard forthcoming).

A related literature explores the relationship between children and happiness (Easterlin 2003). In an early study McLanahan and Adams (1987) used cross sectional data and OLS regressions to conclude that children lower parental happiness. Clark and Oswald (2002) on the other hand used longitudinal data allowing them to control for individual fixed effects. They only found a negative effect of third or higher order children on parental well-being. Controlling for genetic disposition (by using data from identical Danish twins) Kohler, Behrman, and Skytthe (2005) found that the arrival of a first child has a strong positive effect on women's happiness; additional children have a negative effect; and men's happiness does not vary with the number of children, only with whether they are in a partnership with a woman. Nomaguchi and Milkie (2003) found that the happiness effect of becoming a parent is a positive function of whether parents are married or not, and more so for women. Hakim (2003) found that marital satisfactions declined from the time children are born up to the teenage years, and then rises again to former levels after children grow up. 
In this paper we examine how children affect psychic benefits of being in couple by analyzing answers to a unique question in the National Longitudinal Study of Youth's 1997 cohort (NLSY97 hereafter): "How much do you feel that [your current spouse/partner] cares about you?". At the same time we examine how presence of children changes overall happiness level of individuals by using answers to another question in NLSY97: "How much of the time during the last month have you been a happy person?" Since the individuals were interviewed repeatedly over an 11-year timeframe the data allows us to estimate the effect of children on perceived spousal love and overall happiness from intra-personal variation only.

We find that (a) presence of children is associated with a loss of spousal love; (b) loss of spousal love is associated with loss of overall happiness; but (c) presence of children is not associated with significant loss of overall happiness. ${ }^{1}$ If children reduce feelings of being loved by the spouse but do not reduce reported happiness even though spousal love induces happiness, then it must be the case that children contribute to parental happiness by providing other benefits. These other benefits from children could be either material or emotional (what economists have called 'psychic benefits').

Possible material benefits from children include future parental care by adult children (Cigno 1993), tax benefits, and welfare benefits. With the increased importance of social security the value of children as providers of future care of parents has dwindled in industrialized countries and the present value of such benefits is likely to be low when children are mostly under 6 , as is the case in our sample. It has been shown that tax benefits (Whittington 1992) and/or welfare benefits motivate parents; they may also

\footnotetext{
${ }^{1}$ While the first two results are novel, the third result has parallels in the existing literature. In particular, it is consistent with some of the findings of Clark and Oswald (2002) and Kohler, Behrman, and Skytthe (2005).
} 
affect the relationship between children and parental happiness. However, we were able to rule out these explanations in our empirical analysis.

Alternatively, overall happiness may not decrease with presence of children because loss of spousal love is compensated with altruistic feelings towards children. Several studies have proposed altruism towards children as a benefit from children, including Becker (1974), Willis (1974), Becker and Barro (1988). Other studies, including Francesconi (2002), have found that parents derive utility from the existence of children. Schwarze and Winklemann's (2005) finding that parental happiness increases with the happiness of their adult children also suggests that parents have altruistic feelings towards children. Our results can be interpreted as additional (but not conclusive) evidence that is consistent with the altruistic parent argument.

This approach of indirect inference has limitations. Ideally one would like to estimate the net present value (NPV) of the children. Given that our data does not allow us to estimate that NPV, we use change in overall happiness before and after having children as an (imperfect) proxy for NPV of children. Since our empirical results show no change in happiness after having children, we infer that the NPV of children is nonnegative. One may want to argue that no change in happiness implies a zero NPV but we are reluctant to claim this stronger result. Therefore our inferences regarding altruism should be viewed as qualitative and not quantitative results. Furthermore, this approach does not allow us to compare degree of altruism across groups. It allows us to infer about altruism only when we observe a decline in spousal love. If there is no significant decline then we cannot infer (one way or the other) whether the agents have altruistic preferences 
towards their children (because we are inferring only a non-negative, but not necessarily strictly positive, NPV of children).

Our analysis shows some other secondary results. We find that arrival of a new child does not change perceived spousal love, but that changes as the child grows older: presence of (even) one child above age leads to reduced perceived spousal love. We compare perceived spousal loss according to type of relationship and find that marriage has a protective effect for women: the perceived loss of spousal love is smaller for married than for cohabiting women. We further find that religious women perceive a larger decline in spousal love compared to non-religious women, but that the opposite is true for men.

The rest of the paper is as follows: section 2 describes the data and methods, section 3 discusses the results and section 4 concludes.

\section{Data and Methods}

\section{Data}

The data used in this paper is from the NLSY97 which is a nationally representative sample of 9022 youths aged 12-16 as of 31st December, 1996. Data on these individuals were first collected in 1997, and since then data has been collected annually. We use the first 11 waves that are currently available, for the period 1997-2008.

NLSY97 has detailed information about the education, labor force participation and relationship status of the respondents, among others. There is also information on the characteristics of the partners, although not as detailed. In addition, respondents were also asked some unique questions about their perceptions of their spouse/partner. Our research 
centers around the following question: "How much do you feel that [this spouse/partner] cares about you?" Respondents were asked to provide a number between zero and ten, with zero being "not close" and 10 meaning "very close". We use this variable as a proxy of an individual's perception about their spouse's "love" for them.

Another key question we used in our analysis is "How much of the time during the last month have you been a happy person?" Respondents were asked to provide a number between one and four, with one being "all of the time" and four meaning "none of the time". To be symmetric with the spousal love variable we recoded the happiness variable as the inverse of the answers to this question, with 4 being the happy "all of the time" and one being happy "none of the time". Unfortunately this question was asked only during 2000, 2002, 2004, and 2006 interviews.

We constructed two samples: our first sample of 3388 (2320) person-year observations from 1877 (1438) women (men) for whom a measure of happiness is available. The descriptive statistics for this sample, Sample 1, are shown in columns one and two in Table 1. The mean for the spousal love variable is 9.56 for women and 9.42 for men (medians for both groups were 10). However, there was variation in the data as is evident by a standard deviation of around one. Variation in the perception of being loved across individuals at a given point in time is similar to variation in a particular individual's experiences over time. Means for the happiness variable are 2.805 for women and 2.893 for men.

We also estimate associations between children and spousal love for a larger sample described in columns three and four. The larger sample, sample 2, consists of 7357 (5249) person-year observations from 2281 (1875) women (men) who are either 
cohabitating or married (i.e., currently have a partner) for all years for which we have data. The happiness variable is not always available for this sample.

The descriptive statistics in the two samples are similar, but the following describes Sample 2. In the female sample, about $49 \%$ of person-year observations (approximately $51 \%$ of the women) have at least one child present. An overwhelming majority of children are less than six years old. The larger sample allows us to effectively distinguish the effects of birth of a child from the effects of older children. We use six different categories: (1) only one child and the child is an infant (i.e., less than one year old, 8.4\%), (2) only one child and the child is more than one year old (19.0\%), (3) two children with one infant and one child who is more than one year old (5.7\%), (4) two children and both of them more than one year old $(10.2 \%)$, (5) three children with one infant and two children who are more than one year old (2.0\%), and finally (6) three older children or four or more children (3.8\%). For respondents with four or more children, we do not distinguish between infant and older children because we have very few observations in that category.

Table 1 also indicates that average years of education for women (men) were 12.8 (12.4). We calculated the difference between partner and respondent's education, and tabulated these differences separately depending on whether they were positive or negative. For those who had a positive difference it averaged 0.56 in the case of women and 0.36 in the case of men. If partners had the same education this variable was zero. For those who a negative difference it averaged -0.44 in the case of women and -0.55 in the case of men. The average age of women (men) was 22.7 (23.2) years. The differences between partner's and respondent's age were tabulated separately depending on whether 
they were positive or negative. ${ }^{2}$ The average age difference, if positive, was $0.06(0.57)$, and if negative, was $-0.84(-2.7)$ for the female (male) sample. About $15.0 \%(71.2 \%)$ of our female sample and $19.3 \%(64.9 \%)$ of our male sample are Black (White). 52.2\% (47.2\%) of all observations in the female (male) sample are married, the rest are cohabiting. Such a high incidence of cohabitation is not surprising given the low average age of the respondents.

With respect to religion, respondents were categorized into three groups: Catholics (27.1\% in the female sample and $26.6 \%$ in the male sample), Protestants $(56.7 \%$ in the female sample and $54.5 \%$ in the male sample), and individuals with "no religion" $(11.2 \%$ in the female sample and $14.0 \%$ in the male sample). We do no analyze individuals with other religions (like Jewish, Muslim, Hindu or Buddhist) due to small sample sizes.

Religiosity was defined based on a unique question asked in NLSY97: " $R$ believes religious teachings are to be obeyed exactly as written". Those answering "NO" to this question are not necessarily non-religious in the traditional sense but may include the non-religious as well as those who do not take the teachings of religion literally. This group may not adhere to strict interpretations of religious duties (such as procreation), which captures an important aspect of "religiosity" in the current context. $35.2 \%(39.9 \%)$ of respondents in the female (male) sample identify themselves as religious by this definition.

$26.0 \%(15.3 \%)$ of the women (men) were working part time (PT) and about $44.0 \%$ (63.0\%) full time (FT). The NLSY also provides information about the working status of the respondents' spouse/partner: $81.9 \%$ (49.0\%) of women's (men's) partners were

\footnotetext{
${ }^{2}$ If the difference between the respondent's age and spouse's age is less than three then the difference is coded as zero.
} 
employed FT and 7.5\% (18.5\%) PT. These numbers reflect the fact that women have a higher propensity to work PT.

For respondents who were working we use actual hourly wages. All hourly wages are in 1984 dollars. For those who are not working we calculate predicted wages based on the Heckman two-step regression method. ${ }^{3}$ The details of this estimation are available on request. The wage variable reported here is the actual wage for working periods and predicted wage for non-working periods. The average hourly wage was $\$ 6.85$ (\$8.40) for women (men).

The data also have partners' yearly earnings. If that information is not available, we use a method similar to the one described above to estimate earnings. The spousal earnings reported here are actual earnings, if available, and predicted if the actual earnings are not available. Partners' average annual earnings were just under $\$ 15,000$ $(\$ 9,300)$ for the female (male) sample. Again, these are in 1984 dollars. Wages and earnings are not adjusted for geographical variation (that information that is not available in the public version of the data) in cost of living (which adds to the reasons why fixed effect regressions are our preferred method of estimation).

\section{Methods.}

In our empirical analysis we use individual fixed effects (FE) regressions to account for unobserved time-constant heterogeneity. The use of fixed effect regressions has been advocated by Ferrer-i-Carbonell and Frijters (2004) who showed that controlling for the individual level fixed effects is important in happiness studies. They also showed that results obtained from FE Logit and FE regressions are "virtually the same". The use of

\footnotetext{
${ }^{3}$ We use marital status, number, and age of children as identifying variables in the participation equation.
} 
FE regressions implies that the identification of the parameters comes only from intraperson variation over time: any time-constant unobserved heterogeneity is differenced out. Even then, we recognize that this framework does not allow us to conclusively establish a causal relationship.

We estimate the following equation:

$$
y_{i t}=\beta X_{i t}+\gamma \text { Child }_{i t}+\theta_{i}+\varepsilon_{i t}
$$

where the independent variable $y_{i t}$ may be either overall happiness or perception of being loved by a spouse (spousal love) reported by respondent $i$ at time $t$. "Child ${ }_{i t}$ " is a vector that represents the number of children. $X_{i t}$ represent a vector of controls that include both the respondent's and partner's characteristics and $\theta_{i}$ represents individual fixed effects.

We also estimate ordered logit regressions of spousal love defined as a discrete variable taking values between zero and ten.

\section{Results}

We first report results for female and male respondents (married or cohabiting with a partner) for both the independent variables--spousal love and overall happiness--based on the first sample. Then, using the larger samples, we further explore how existence of children affects perceived spousal love for various combinations of number and age of children and for groups differing in race, marital status, and religion. We could not do the first part of the analysis using the larger sample because the happiness variable is not available for all years.

Table 2 presents regression results for all women and men who live in couple, regardless of whether they are married or not. The first two columns show how the 
existence of children affects perceived spousal love and the next four columns show how the existence of children affects overall happiness. Columns one, three, and five present results for women and columns two, four, and six present results for men.

Column 1 shows that women perceive a decline in spousal love when children are present: women with one child perceive a reduction of 0.20 units; with two children a reduction of 0.37 units; and with three or more children a reduction of 0.44 units. The loss of perceived spousal love thus increases as the number of children grows, but less than proportionately. For men (column 2) only the first child is associated with a statistically significant reduction in perceived spousal love.

Focusing on columns three and four we find that the presence of children is not associated with any change in overall happiness. All the coefficients of children (for both men and women) are statistically insignificant. Next, in columns five and six, we add spousal love as an additional explanatory variable in the happiness regressions. We find that for both men and women spousal love and overall happiness are strongly and positively correlated. We also find that for women spouse's work is a major contributor to overall happiness (but not spouse's income).

We thus find that children reduce feelings of being loved by a spouse but do not reduce reported happiness, even though spousal love affects happiness. It must therefore be the case that children contribute to parental happiness by providing other benefits to parents. These other benefits from children could be either material or emotional and can be viewed as compensation for foregone perceived spousal love. Altruism towards children is a plausible explanation for our combined findings on spousal love and happiness, but it is not the only possible way by which a decrease in happiness associated 
with lower spousal love could possibly be compensated. Alternatively, parents may have higher disposable income when children are present than before they have children, possibly because after having a child they qualify for welfare payments or in-kind government transfers or pay fewer taxes.

Since these welfare and tax benefits are observable we ascertain the plausibility of such explanation by further analysis, focusing on two of the most important programs: Temporary Assistance to Needy Families (TANF) and Earned Income Tax Credit. We restrict our attention to women only since less than $0.25 \%$ of men receive any TANF benefit. Although the EITC take up rate among men is higher (compared to TANF participation) the results for men are similar regardless of whether EITC recipients are included or not. To ascertain whether welfare benefits are driving our results we restrict our sample to individuals who did not participate in welfare program. All respondents who had been on TANF for even one month in a year were dropped. Imposing this restriction reduces our sample size from 3388 to 3280, as TANF participation is less than $3 \%$ in our female sample. We present the results in columns one, three, and five of Table 3. From Table 3 onwards we only present the coefficients associated with the "children" variable. As in Table 2, the results show that women perceive a reduction in spousal love after children are born but no change in overall happiness. We take this as evidence that welfare benefits are not compensating for loss of spousal love.

Next we analyze whether tax benefits in the form of EITC are driving our results. To do so we exclude any woman who participated either in TANF or applied for an EITC in any given year. This restriction further reduces our sample size to 2378 person-year observations from 1536 women. Results for this sample are shown in columns two, four, 
and six of Table 3. Again it can be seen that women perceive a reduction in spousal love after children are born but they don't experience a change in overall happiness. Therefore we conclude that neither tax nor welfare benefits compensate for the loss of spousal love. Having excluded material benefits from children as possible compensation for loss of spousal love we interpret the combined results reported in Tables 2 and 3: parents' altruistic feelings lead them to experience increased happiness after they have children whereas feelings of being loved by their spouses decrease, entailing lower happiness.

Next, using the larger sample, we investigate (1) whether child's age (whether the child is an infant or not) matters, as opposed to simply the number of children, and (2) whether the cost of children in terms of foregone spousal love varies across subgroups. With these goals in mind we rerun the spousal love regressions on the bigger sample, but we can't re-estimate happiness regressions as that information is missing for many of the years we observe.

Age of children. Columns 1 and 4 in Table 4 present regression results for all individuals who live in couple, regardless of whether they are married or not. This time a distinction is made between infants and older children defined as children older than one. The first (fourth) column presents results for women (men). Again, we find that the presence of children reduces women's perception of being loved compared to that of women without any children. The only exception being women with only one infant: they don't experience a loss in perceived spouse's love. Women with one older child perceive a reduction in spouse's love of 0.32 units (about one third of one standard deviation).

With the arrival of a second infant (in addition to one older child) perceived reduction in spouse's love changes from -0.32 to -0.29 . We cannot reject the hypothesis that the 
coefficients are the same, which indicates that the arrival of a second infant has no additional adverse effect on a woman's perception of being loved by her partner. As the second infant becomes older i.e., there are two older children, perceived spouse's love decreases by -0.51 units (about one half of one standard deviation), which differs significantly from the effect of one older child. Presence of even more children in the household does not add significantly to the cost of children in terms of foregone spousal love, but this finding should be treated carefully because less than 5\% of women in our sample have three or more children. In contrast to what we found for women, in the case of men most of the children dummies are statistically insignificant (column 4). By comparing tables 2 and 4 we learn that for both men and women it is the presence of one older child that is associated with less perceived spousal love, not the presence of an infant.

The result that during the year after a child's birth people don't feel less loved by their partner could reflect that when children are young, both parents are more likely to be emotionally invested in the child, especially if the child was planned. Therefore, any action by one parent that improves the quality of life of the child is likely to generate utility for the other parent. In this case utility from children and spousal love are produced jointly. It may also reflect Warm Glow altruism associated with the act of giving (Becker 1974, Andreoni 1989, 1990). As infants turn into toddlers, parents may perceive more of a decline in spousal love as their partners invest more time into childcare (and the warm glow fades away) and spend less time taking care of their own needs and love for spouse and love for child are less likely to be produced jointly. Next, we turn to some comparisons across groups. 
Parental gender. An association between decline in perceived spousal love and number of children is observed for a wider range of family constellations in the case of women than in the case of men. Men only report a lower level of spousal love in the case of one older child. This could be explained in terms of women incurring more of the time costs of children than men (Sevilla-Sanz and Gimenez 2012). In couples with a traditional division of labor men may increase their time in the labor force after a first child's birth, whereas women increase their time in household production. Both effects may reduce the time they have to demonstrate love to each other, resulting in less perceived spousal love. The presence of a second child may not affect men's labor supply as much as it affects women's time in household production. The more women devote time to childcare and away from taking care of their spouse's needs the more they may experience a reduction in perceived spousal love. The loss for women with two children thus exceeds that for men with two children.

We find that women's spousal love losses increase with number of children, but that the increases are less than proportional to number of children. This may reflect economies of scale in caring for children: the extra work generated by two children may not be double that of one child. Alternatively, this lack of proportionality may be the result of a selection process: respondents in couples characterized with more enduring love or stronger preferences for children (possibly due to more altruism towards children) may choose to have more children than other respondents.

The gender differences that we find could possibly reflect higher altruistic inclinations in women, as hypothesized by sociobiologists (e.g. Wilson 1985), and could be related to findings that women are more altruistic than men in an experimental setting 
(Andreoni and Vesterlund (2001) and Innocenti and Pazienza (2006)). However we should note that our method of indirect inference does not allow us to compare degree of altruism across groups.

Black/white differences. Looking at the estimates by race (cols. 2, 3, 5 and 6 in Table 4) reveals that the reduction in perceived spouse's love due to the presence of children is larger for black women than for white women. Columns 2 and 3 show that for black (white) women one older child is associated with a loss of $0.46(0.29)$ units of spouse's love whereas two older children are associated with a loss of 0.77 (0.43) units.

Marital Status. In the regressions presented so far married and cohabitating couples were pooled together. To determine whether married and unmarried respondents differ in association between spousal love and number of children we estimated separate regression equations for married and cohabiting couples. Table 5 presents results for women (first two columns) and men (last two columns).

The finding that infants are not associated with any reduction in perceived spouse's love applies to both married and cohabiting couples. So does the finding that once children reach their first birthday they entail a cost in terms of foregone perceived spouse's love. However, we observe interesting contrasts between cohabitants and married couples. First, focusing on women, a comparison of columns 1 and 2 in Table 4 indicates that the perceived loss of spousal love reported by cohabiting women exceeds that reported by married women: (1) the presence of one child over the age of one is associated with a 0.18 unit drop in perceived spouse's love among married women in contrast with a 0.49 unit drop among cohabiting women, and (2) when two children over 
the age of one are present married women perceive a decline in spouse's love of 0.35 units whereas cohabiting women perceive a decline of 0.68 units.

Second, for men only the coefficient of one older child is significant but it varies little by marital status. These results are consistent with Nomaguchi and Milkie's (2003) findings that having children reduces parental happiness less when parents are married, and that this is more so for women.

That the costs of children in terms of foregone spousal love are larger for cohabiting women than for married women suggests that marriage has a protective effect for women. This may happen if, relative to live-in boyfriends, husbands are more likely to appreciate children. In turn, this could be the case if marriage encourages men to be more altruistic towards their children and their children's mothers or if married couples are more likely to share the same children than is the case with unmarried couples.

If marriage protects spousal love for mothers but not for fathers it follows that women will be motivated to marry in order to reduce their expected costs of having children, but men not. This finding helps explain why, on average, women seem to be more interested in getting a ring on their finger than men (Grossbard-Shechtman 1993, Mukhopadhyay 2008) and fits well with other protective effects of marriage documented in the literature (e.g. by Waite and Gallagher 2000).

Religion and Religiosity. Religion measures religious affiliation. We combined the different denominations of Protestants into one group and then estimated the regressions for three different groups: Catholics, Protestants, and No Religion. ${ }^{4}$ Table 6 presents the results by religion. Table 7 reports results separately for religious and non-religious individuals, where religiosity was defined in terms of adherence to strict interpretations

\footnotetext{
${ }^{4}$ Respondents from other religions were excluded because of small sample sizes.
} 
of religious duties (such as procreation). The non-religious include those who are more liberal in their views on religion as well as those who define themselves as non-religious.

Column 1 of Table 6 indicates that Catholic women are the only group experiencing a statistically significant loss of spousal love with the arrival of an infant. It appears from Table 6 that in terms of the association between spousal love and number and age of children there are few differences between the three religious groups. Catholics and Protestants appear to react similarly to the presence of children, and so do those with "no religion' group, but due to the small sample size results for this group are not statistically significant.

From Table 7 it appears that child-associated losses of spousal love are larger for religious women than for non-religious women, but that the opposite is the case for men. The statistically significant religious differences are for two or more older children: for women we find a spousal love loss of 0.57 units if they are religious and 0.43 units if they are not. In contrast, in the male sample we find the opposite religiosity differential: a statistically insignificant loss for religious men but a love loss of 0.39 units for nonreligious men. In the case of women, religiosity may mean less of a willingness to have abortions. Consequently, religious people are more likely to have unplanned children and religious women are expected to bear more of the costs of a religious prohibition on abortions. This explains why religious women perceive a larger decline in spousal love.

The analysis so far assumed that spousal love is a linear variable which is an appropriate approach given the results of Ferrer-i-Carbonell and Frijters (2004). To check if non-linear models would produce substantially different results we also estimated an ordered logit model where spouse's love is treated as a discrete variable which can take 
any value between zero and ten. The results from the ordered logit regressions are presented in Table A1 in the appendix (for both the female and male sample). These regressions include a full set of controls but no individual fixed effects. Therefore the logit regression results are not strictly comparable to results presented above.

The results show the predicted probability (based on the ordered logit model) of respondents feeling maximum perceived love from spouse (i.e. spousal love $=10$ ). We report only for this value because in all cases this category has the highest mass (more than $60 \%$ in all cases) in the data. For example, the second row in the first two columns shows that presence of one older child reduces probability that a woman will perceive maximum love from her spouse by 9.8 percentage points, the corresponding reduction for men being 6.0 percentage points. Overall results for women are qualitatively similar to the results for the continuous spousal love variable and fixed effects. For men, however, we find that using ordered logit without fixed effects the impact of children on perceived spousal love is significant and negative not only if there is one child older than 1 but also when there are two or more children. These results are more similar to linear regression results without fixed effects (not presented here). In any event, it is preferable to include fixed effects and our earlier results are the ones we prefer to emphasize.

\section{Conclusions}

Analyses of fertility and child-related decisions invariably look at the costs of children, but so far these have not included the cost of foregone spousal love. We have shown that children can also be costly in the sense that they are associated with loss of spousal love. We find that compared to when they did not have any children, the individuals in our sample reported feeling significantly less loved by their partners when 
they had at least one child. In the case of men loss of reported spousal love is limited to fathers of one child older than one. Women's loss of spousal love grows with number of children.

We also find that spousal love contributes to overall happiness, but happiness does not vary with presence of children. Combined, these two results and the finding of a negative association between spousal love and presence of children suggest that parents must be getting compensated for the loss of perceived spousal love so that their overall happiness is not changing. This compensation could include benefits from children that are of a material nature, such as future parental care by adult children, but in industrialized countries such care has become increasingly less relevant as a force motivating fertility. Alternatively, one may argue that tax or welfare benefits may compensate for the loss of spousal love. However, when we restrict our sample to women who have not received any welfare (TANF) or tax (EITC) benefits, we still get the same results as described above, suggesting that welfare or tax benefits are not the compensating mechanisms. The explanation we favor is that the compensating benefits from children are altruistic in nature.

We also find that relative to men women report more loss of spousal love when they have children, married women experience less of a loss of spousal love than cohabiting women, and religious men experience less of a love loss than non-religious men. The last two findings could be related. Married women obtain more loving commitment from the men with whom they have children, thus experiencing less loss of spousal love. Similarly, religious men may be more committed to the mothers of their children. One may be inclined to infer that what marriage is to women, religion is to men. In contrast, 
marriage does not have parallel effects on men's association between children and spousal love, and religious women don't report less loss of spousal love after becoming mothers. Could it be that institutions such as marriage and religion have more impact on men's expressions of commitment and love than on women's? The male/female differences that we find could be related to differences discussed in sociobiological theories and reported by experimental economists.

Unfortunately, our approach of indirect inference does not permit to clearly determine group differences in degree of altruism: if group B perceives a smaller (or no) decline than group A then we cannot conclude that group B is less altruistic or not altruistic at all. However, we are comfortable inferring that if a group perceives a large decline in spousal love following a childbirth then that group may have altruistic preferences (since they are willing to accept this cost for a greater good). Altruism towards children is not the only mechanism that can explain our results, but is a plausible one. Some alternative explanations, such as children's contributions to parents' higher income via welfare or tax benefits, were eliminated.

In that sense, we contribute an additional piece of evidence to the literature on altruism in the family. Our research on the determinants of spousal love is also interesting in its own right as social scientists increasingly study the determinants of emotions such as love.

Acknowledgements. We thank the referees, J. Ignacio Gimenez, Lawrence Iannaconne, Pierre-Guillaume Meon, Ariane Sarfadz, and participants at seminars at Chapman University and the Brussels School of Economics and Management for helpful comments. 


\section{References}

Andreoni, J. (1989). Giving with impure altruism: Applications to charity and Ricardian equivalence, Journal of Political Economy, 97(6), 1447-58.

Andreoni, J. (1990). Impure altruism and donations to public goods: A theory of warm-glow giving. Economic Journal, 100 (401), 464-477.

Andreoni J., \& Vesterlund, L. (2001). Which is the fair sex? Gender differences in altruism. The Quarterly Journal of Economics, 116(1), 293-312.

Becker, G.S. (1960). An economic analysis of fertility, in Demographic and Economic Change in Developed Countries, Princeton, NJ, Princeton University Press.

Becker, G.S. (1974). A theory of social interactions. Journal of Political Economy, 82 (6), 1063-93.

Becker, G.S., \& Barro, R.J. (1988). A reformulation of the economic theory of fertility. The Quarterly Journal of Economics, 100(412), 1-25.

Bryan, M.L., \& Sevilla-Sanz, A. (2011). Does housework lower wages? Evidence for Britain. Oxford Economic Papers, 63(1), 187-210.

Cigno, A., 1993. Intergenerational transfers without altruism: Family, market and state. European Journal of Political Economy, 9(4), 505-518.

Clark, A.E. \& Oswald, A.J. (2002). A simple statistical method for measuring how life events affect happiness. International Journal of Epidemiology, 31(6), 1139-1144.

Craig, L. \& Bittman, M. (2008). The incremental time costs of children: an analysis of children's impact on adult time use in Australia. Feminist Economics, 14(2): 59-88.

Easterlin, R.A. (2003). Explaining happiness, Proceedings of the National Academy of Sciences, 100(19), 11176-11183.

Ekert-Jaffe, O., \& S. Grossbard (forthcoming). Time cost of children as parents' foregone leisure. Mathematical Population Studies.

Ferrer-i-Carbonell, A., \& Frijters, P. (2004). How important is methodology for the estimates of the determinants of happiness? Economic Journal, 114, 641-659.

Francesconi, M. (2002). A joint dynamic model of fertility and work of married women. Journal of Labor Economics, 20(2), 336-380. 
Giannelli, G.C., Mangiavacchi, L. \& Piccoli, L. (2012). GDP and the value of family caretaking: how much does Europe care? Applied Economics, 44(16), 2111-2131.

Gimenez-Nadal, J. I., \& Sevilla-Sanz, A. (2012). Trends in time allocation: a crosscountry analysis. European Economic Review, 56(6): 1338-1359.

Grossbard-Shechtman, S.A. (1993). On the Economics of Marriage. Boulder (CO): Westview Press.

Gustafsson, B., \& Kjulin, U. (1994). Time use in child care and housework and the total cost of children. Journal of Population Economics, 7(3), 287-306.

Gutiérrez-Domènech, M. (2010). Parental employment and time with children in Spain. Review of Economics of the Household, 8(3), 371-391.

Hakim, C. (2003). Lifestyle preferences and patriarchal values: causal and non-causal attitudes and values in Changing Life Patterns in Western Industrial Societies (eds) J. Z. Giele and E. Holst, Elsevier.

Innocenti, A., \& Pazienza, M. G. (2006). Altruism and gender in the trust game. Labsi Working Paper No. 5/2006. Available at SSRN: http://ssrn.com/abstract=884378

Kohler, H.-P., J.R. Behrman, \& Skytthe, A. (2005). Partner + children = happiness? An assessment of the effect of fertility and partnerships on subjective well-being in Danish twins. Population and Development Review, 31(3), 407-445.

McLanahan, S. \& Adams, J. (1987). Parenthood and psychological wellbeing. Pp. 237257 in Annual Review of Sociology. Turner and Short (eds.). Palo Alto, CA: Annual Reviews, Inc.

Mincer, J. (1962). Labor Force Participation of Married Women: a Study of Labor Supply, in H. Gregg Lewis (ed.) Aspects of Labor Economics. Princeton, N.J.: Princeton University Press.

Mincer, J. (1963). Market Prices Opportunity costs and income effects, in Measurement in Economics, (ed.) C. Christ, et al., Stanford, CA: Stanford University Press.

Mukhopadhyay, S. (2008). Do women value marriage more? The effect of obesity on cohabitation and marriage in the USA. Review of Economics of the Household, 6(2), 111126.

Nomaguchi, K. M., \& Milkie, M. A. (2003). Costs and rewards of children: The effects of becoming a parent on adults' lives. Journal of Marriage and Family, 65(2), 356 374. 
Schwarze, J., \& Winkelmann, R. (2005). What can happiness research tell us about altruism? Evidence from the German Socio-Economic Panel. Discussion Paper 1487, IZA.

Waite, L., \& Gallagher, M. (2000). The Case for Marriage. Broadway Books.

Waldfogel, J. (1998). Understanding the 'family gap' in pay for women with children. Journal of Economic Perspectives, 12(1), 137-156.

Whittington, Leslie A. Taxes and the family: the impact of the tax exemption for dependents on marital fertility. Demography, 29(2), 215-226

Willis, R.J. (1974). A new approach to the economic theory of fertility behavior. In T. W. Schultz (Ed.), Economics of the Family. Chicago: University of Chicago Press.

Wilson, E.O. (1985). Sociobiology. Cambridge: Harvard University Press. 
Table 1: Descriptive statistics

\begin{tabular}{|c|c|c|c|c|}
\hline & \multicolumn{2}{|c|}{ Sample 1} & \multicolumn{2}{|c|}{ Sample 2} \\
\hline & Women & Men & Women & Men \\
\hline Spousal love ( 1 to 10,10 is maximum) & 9.555 & 9.424 & 9.557 & 9.454 \\
\hline Happiness ( 1 to 4,4 is maximum) & $\begin{array}{c}2.805 \\
(0.637\end{array}$ & $\begin{array}{c}2.893 \\
(0.639)\end{array}$ & 4) & 1.11 \\
\hline One child $(<1) \%$ & & & $\begin{array}{l}0.0841 \\
(0.278)\end{array}$ & $\begin{array}{l}0.0981 \\
(0.297)\end{array}$ \\
\hline One child $(>1) \%$ & & & $\begin{array}{c}0.190 \\
(0.392)\end{array}$ & $\begin{array}{c}0.199 \\
(0.399)\end{array}$ \\
\hline Two children $(<1,>1) \%$ & & & $\begin{array}{l}0.0571 \\
(0.232)\end{array}$ & $\begin{array}{l}0.0528 \\
(0.224)\end{array}$ \\
\hline Two children $(>1) \%$ & & & $\begin{array}{c}0.102 \\
(0.303)\end{array}$ & $\begin{array}{l}0.0754 \\
(0.264)\end{array}$ \\
\hline Two children $(<1,>1,>1) \%$ & & & $\begin{array}{l}0.0201 \\
(0.140)\end{array}$ & $\begin{array}{l}0.0130 \\
(0.113)\end{array}$ \\
\hline Three older $(>1)$ children or more $\%$ & & & $\begin{array}{l}0.0375 \\
(0.190)\end{array}$ & $\begin{array}{l}0.0290 \\
(0.168)\end{array}$ \\
\hline One child \% & $\begin{array}{c}0.273 \\
(0.445)\end{array}$ & $\begin{array}{c}0.302 \\
(0.459)\end{array}$ & $\begin{array}{c}0.274 \\
(0.445)\end{array}$ & $\begin{array}{c}0.296 \\
(0.456)\end{array}$ \\
\hline Two children $\%$ & $\begin{array}{c}0.151 \\
(0.358)\end{array}$ & $\begin{array}{c}0.114 \\
(0.318)\end{array}$ & $\begin{array}{c}0.159 \\
(0.366)\end{array}$ & $\begin{array}{c}0.128 \\
(0.334)\end{array}$ \\
\hline Three or more children $\%$ & $\begin{array}{l}0.0502 \\
(0.218)\end{array}$ & $\begin{array}{l}0.0397 \\
(0.195)\end{array}$ & $\begin{array}{c}0.057 \\
(0.233)\end{array}$ & $\begin{array}{c}0.042 \\
(0.200)\end{array}$ \\
\hline Education (years of) & $\begin{array}{c}12.73 \\
(2.168)\end{array}$ & $\begin{array}{c}12.40 \\
(3.207)\end{array}$ & $\begin{array}{c}12.82 \\
(2.243)\end{array}$ & $\begin{array}{c}12.43 \\
(3.348)\end{array}$ \\
\hline Positive difference partner - own educ & $\begin{array}{c}0.516 \\
(1.148)\end{array}$ & $\begin{array}{c}0.347 \\
(0.873)\end{array}$ & $\begin{array}{c}0.560 \\
(1.197)\end{array}$ & $\begin{array}{c}0.356 \\
(0.880)\end{array}$ \\
\hline Negative difference partner - own educ & $\begin{array}{c}-0.401 \\
(0.982)\end{array}$ & $\begin{array}{c}-0.475 \\
(1.073)\end{array}$ & $\begin{array}{c}-0.435 \\
(1.024)\end{array}$ & $\begin{array}{c}-0.547 \\
(1.154)\end{array}$ \\
\hline Age (years) & $\begin{array}{c}22.38 \\
(2.118)\end{array}$ & $\begin{array}{c}22.87 \\
(1.976)\end{array}$ & $\begin{array}{c}22.74 \\
(2.221)\end{array}$ & $\begin{array}{c}23.19 \\
(2.079)\end{array}$ \\
\hline Positive Age difference ( $>3$, partner - own $)$ & $\begin{array}{l}0.0555 \\
(0.461)\end{array}$ & $\begin{array}{c}0.529 \\
(1.326)\end{array}$ & $\begin{array}{l}0.0613 \\
(0.482)\end{array}$ & $\begin{array}{c}0.557 \\
(1.373)\end{array}$ \\
\hline Negative Age difference ( $>3$, partner - own) & $\begin{array}{c}-2.706 \\
(3.701)\end{array}$ & $\begin{array}{l}-0.841 \\
(2.393)\end{array}$ & $\begin{array}{c}-2.700 \\
(3.730)\end{array}$ & $\begin{array}{c}-0.837 \\
(2.394)\end{array}$ \\
\hline Black \% & $\begin{array}{c}0.150 \\
(0.357)\end{array}$ & $\begin{array}{c}0.192 \\
(0.394)\end{array}$ & $\begin{array}{c}0.150 \\
(0.357)\end{array}$ & $\begin{array}{c}0.193 \\
(0.394)\end{array}$ \\
\hline White $\%$ & $\begin{array}{c}0.712 \\
(0.456)\end{array}$ & $\begin{array}{c}0.645 \\
(0.478)\end{array}$ & $\begin{array}{c}0.712 \\
(0.453)\end{array}$ & $\begin{array}{c}0.649 \\
(0.477)\end{array}$ \\
\hline Married \% (otherwise cohabit) & $\begin{array}{c}0.508 \\
(0.500)\end{array}$ & $\begin{array}{c}0.467 \\
(0.499)\end{array}$ & $\begin{array}{c}0.522 \\
(0.499)\end{array}$ & $\begin{array}{c}0.472 \\
(0.499)\end{array}$ \\
\hline Catholic \% & $\begin{array}{c}0.272 \\
(0.445)\end{array}$ & $\begin{array}{c}0.268 \\
(0.443)\end{array}$ & $\begin{array}{c}0.271 \\
(0.444)\end{array}$ & $\begin{array}{c}0.266 \\
(0.442)\end{array}$ \\
\hline Protestant $\%$ & $\begin{array}{c}0.566 \\
(0.495)\end{array}$ & $\begin{array}{c}0.538 \\
(0.498)\end{array}$ & $\begin{array}{c}0.567 \\
(0.495)\end{array}$ & $\begin{array}{c}0.545 \\
(0.498)\end{array}$ \\
\hline No religion $\%$ & $\begin{array}{c}0.114 \\
(0.318)\end{array}$ & $\begin{array}{c}0.143 \\
(0.350)\end{array}$ & $\begin{array}{c}0.112 \\
(0.316)\end{array}$ & $\begin{array}{c}0.140 \\
(0.347)\end{array}$ \\
\hline Religious \% & $\begin{array}{c}0.354 \\
(0.478)\end{array}$ & $\begin{array}{c}0.403 \\
(0.490)\end{array}$ & $\begin{array}{c}0.352 \\
(0.477)\end{array}$ & $\begin{array}{c}0.399 \\
(0.489)\end{array}$ \\
\hline Working part time $\%$ & $\begin{array}{c}0.251 \\
(0.434)\end{array}$ & $\begin{array}{c}0.151 \\
(0.358)\end{array}$ & $\begin{array}{c}0.260 \\
(0.438)\end{array}$ & $\begin{array}{c}0.153 \\
(0.360)\end{array}$ \\
\hline Working full time $\%$ & 0.438 & 0.618 & 0.440 & 0.630 \\
\hline
\end{tabular}


Spouse working part time $\%$

Spouse working full time \%

Hourly wage (\$, actual or predicted)

Spouse's annual income (\$, actual or predicted)

Observations

Number of id $\begin{array}{llll}(0.496) & (0.486) & (0.496) & (0.483)\end{array}$

$\begin{array}{llll}0.0756 & 0.186 & 0.0754 & 0.185\end{array}$

$\begin{array}{llll}(0.264) & (0.389) & (0.264) & (0.389)\end{array}$

$\begin{array}{llll}0.816 & 0.478 & 0.819 & 0.490\end{array}$

$\begin{array}{llll}(0.388) & (0.500) & (0.385) & (0.500)\end{array}$

$\begin{array}{llll}6.600 & 8.148 & 6.852 & 8.400\end{array}$

$\begin{array}{llll}(6.785) & (10.76) & (7.417) & (11.04)\end{array}$

$\begin{array}{llll}14,798 & 9,173 & 14,999 & 9,296\end{array}$

$\begin{array}{llll}(12,028) & (6,614) \quad(10,328) & (5,570)\end{array}$

$\begin{array}{llll}3,388 & 2,320 & 7,357 & 5,249\end{array}$

$1,877 \quad 1,438 \quad 2,281 \quad 1,875$


Table2: Fixed Effects linear regressions of spousal love and happiness

\begin{tabular}{|c|c|c|c|c|c|c|}
\hline & \multicolumn{2}{|c|}{ Spousal love } & \multicolumn{4}{|c|}{ Happiness } \\
\hline & Women & Men & Women & Men & Women & Men \\
\hline \multirow[t]{2}{*}{ Spousal love } & & & & & 0.065 & 0.090 \\
\hline & & & & & $(4.32)^{* * *}$ & $(5.18)^{* *}$ \\
\hline \multirow[t]{2}{*}{ One child } & -0.196 & -0.355 & 0.049 & -0.039 & 0.061 & -0.007 \\
\hline & $(2.33)^{*}$ & $(2.73)^{* *}$ & $(0.96)$ & $(0.61)$ & $(1.22)$ & $(0.10)$ \\
\hline \multirow[t]{2}{*}{ Two children } & -0.373 & -0.295 & -0.057 & -0.067 & -0.033 & -0.041 \\
\hline & $(2.92)^{* *}$ & $(1.45)$ & $(0.84)$ & $(0.70)$ & $(0.48)$ & $(0.44)$ \\
\hline \multirow[t]{2}{*}{ Three or more children } & -0.437 & -0.562 & -0.063 & 0.037 & -0.034 & 0.088 \\
\hline & $(2.12)^{*}$ & $(1.68)$ & $(0.62)$ & $(0.26)$ & $(0.34)$ & $(0.63)$ \\
\hline \multirow[t]{2}{*}{ Education } & 0.033 & -0.006 & 0.032 & -0.010 & 0.030 & -0.010 \\
\hline & $(0.91)$ & $(0.72)$ & $(1.68)$ & $(2.56)^{*}$ & $(1.55)$ & $(2.30)^{*}$ \\
\hline Positive Education & -0.028 & -0.012 & -0.024 & 0.021 & -0.022 & 0.022 \\
\hline difference & $(0.85)$ & $(0.20)$ & $(1.56)$ & $(0.81)$ & $(1.48)$ & $(0.91)$ \\
\hline Negative Education & -0.019 & 0.023 & -0.005 & 0.030 & -0.004 & 0.028 \\
\hline difference & $(0.52)$ & $(0.48)$ & $(0.25)$ & $(1.25)$ & $(0.18)$ & (1.19) \\
\hline \multirow[t]{2}{*}{ Age } & -0.010 & -0.018 & -0.003 & -0.011 & -0.003 & -0.009 \\
\hline & $(0.57)$ & $(0.55)$ & $(0.37)$ & $(0.79)$ & $(0.32)$ & $(0.71)$ \\
\hline Positive Age & 0.114 & 0.145 & 0.035 & 0.061 & 0.028 & 0.048 \\
\hline difference $(>3)$ & $(1.35)$ & $(2.21)^{*}$ & $(0.79)$ & $(1.92)$ & $(0.61)$ & $(1.48)$ \\
\hline Negative Age & -0.005 & 0.017 & 0.005 & 0.002 & 0.006 & 0.001 \\
\hline difference $(>3)$ & $(0.24)$ & $(0.21)$ & $(0.41)$ & $(0.10)$ & $(0.44)$ & $(0.04)$ \\
\hline \multirow[t]{2}{*}{ Part time work } & 0.034 & -0.391 & 0.037 & -0.050 & 0.034 & -0.015 \\
\hline & $(0.51)$ & $(2.03)^{*}$ & $(0.89)$ & $(0.66)$ & $(0.83)$ & $(0.20)$ \\
\hline \multirow[t]{2}{*}{ Full time work } & -0.066 & -0.151 & -0.035 & -0.038 & -0.031 & -0.024 \\
\hline & $(1.00)$ & $(0.78)$ & $(0.78)$ & $(0.58)$ & $(0.70)$ & $(0.37)$ \\
\hline spouse & -0.266 & 0.057 & 0.170 & -0.119 & 0.187 & -0.124 \\
\hline part time work & $(2.02)^{*}$ & $(0.41)$ & $(2.36)^{*}$ & $(1.79)$ & $(2.63)^{* * *}$ & $(1.91)$ \\
\hline spouse & 0.041 & -0.027 & 0.176 & 0.015 & 0.173 & 0.017 \\
\hline full time work & $(0.41)$ & $(0.23)$ & $(3.55)^{* *}$ & $(0.28)$ & $(3.53)^{* * *}$ & $(0.33)$ \\
\hline Log of hourly wage & -0.035 & 0.018 & -0.085 & -0.021 & -0.081 & -0.022 \\
\hline Log of spouse's & $(0.62)$ & $(0.17)$ & $(1.86)$ & $(0.38)$ & $(1.78)$ & $(0.43)$ \\
\hline \multirow[t]{2}{*}{ Annual income } & 0.045 & 0.025 & 0.023 & 0.112 & 0.021 & 0.112 \\
\hline & $(0.73)$ & $(0.21)$ & $(1.88)$ & $(2.12)^{*}$ & $(1.74)$ & $(2.16)^{*}$ \\
\hline \multirow[t]{2}{*}{ Constant } & 9.138 & 9.931 & 2.404 & 3.096 & 1.796 & 2.186 \\
\hline & $(12.08) * *$ & $(9.79)^{* * *}$ & $(8.97)^{* *}$ & $(12.11)^{* *}$ & $(5.99)^{* * *}$ & $(7.34)^{* * *}$ \\
\hline Observations & 3388 & 2320 & 3388 & 2320 & 3388 & 2320 \\
\hline Number of id & 1877 & 1438 & 1877 & 1438 & 1877 & 1438 \\
\hline
\end{tabular}

$*$ : significant at 5\%, **: significant at $1 \%$ 
Table 3: Children, spousal love, and happiness: role of tax and/or welfare benefits; women's sample

\begin{tabular}{|l|l|l|l|l|l|l|}
\hline & \multicolumn{2}{|c|}{ Spousal love } & \multicolumn{4}{c|}{ Happiness } \\
\hline & $\begin{array}{l}\text { No } \\
\text { welfare }\end{array}$ & $\begin{array}{l}\text { No welfare } \\
\text { No EITC }\end{array}$ & $\begin{array}{l}\text { No } \\
\text { welfare }\end{array}$ & $\begin{array}{l}\text { No welfare } \\
\& \\
\text { No EITC }\end{array}$ & $\begin{array}{l}\text { No } \\
\text { welfare }\end{array}$ & $\begin{array}{l}\text { No welfare } \\
\& \\
\text { No EITC }\end{array}$ \\
\hline Spousal love & & & & & 0.063 & 0.079 \\
\hline & & & & & $(4.18)^{* *}$ & $(4.00)^{* *}$ \\
\hline One child & -0.179 & -0.231 & 0.047 & 0.004 & 0.058 & 0.022 \\
\hline & $(2.14)^{*}$ & $(2.04)^{*}$ & $(0.91)$ & $(0.06)$ & $(1.14)$ & $(0.33)$ \\
\hline Two children & -0.352 & -0.558 & -0.065 & -0.096 & -0.042 & -0.052 \\
\hline & $(2.68)^{* *}$ & $(2.73)^{* *}$ & $(0.94)$ & $(0.99)$ & $(0.61)$ & $(0.52)$ \\
\hline $\begin{array}{l}\text { Three or more } \\
\text { children }\end{array}$ & -0.444 & -0.566 & -0.100 & -0.174 & -0.072 & -0.129 \\
\hline & $(1.99)^{*}$ & $(1.97)^{*}$ & $(0.93)$ & $(1.12)$ & $(0.68)$ & $(0.82)$ \\
\hline Observations & 3280 & 2378 & 3280 & 2378 & 3280 & 2378 \\
\hline Number of id & 1827 & 1536 & 1827 & 1536 & 1827 & 1536 \\
\hline
\end{tabular}

Notes:

Fixed Effects Linear Regressions.

Controls include Education, positive education difference, negative education difference, age, positive age difference (>3), negative age difference (>3), part time work status, full time work status, spouse working part time work, spouse working full time work, log of hourly wage, log of spouse's annual income and a constant.

$*$ : significant at $5 \%, * *$ : significant at $1 \%$ 
Table 4: Children and spousal love: number and age of children

\begin{tabular}{|l|l|l|l|l|l|l|}
\hline & \multicolumn{3}{|c|}{ Women } & \multicolumn{3}{c|}{ Men } \\
\hline & All & White & Black & All & White & Black \\
\hline One child (<1) & -0.078 & -0.015 & -0.177 & -0.101 & -0.053 & -0.240 \\
\hline & $(1.66)$ & $(0.28)$ & $(1.34)$ & $(1.48)$ & $(0.73)$ & $(1.02)$ \\
\hline One child (>1) & -0.322 & -0.288 & -0.462 & -0.318 & -0.354 & -0.178 \\
\hline & $(5.21)^{* *}$ & $(4.22)^{* *}$ & $(2.16)^{*}$ & $(3.53)^{* *}$ & $(3.48)^{* *}$ & $(0.63)$ \\
\hline Two children (<1, >1) & -0.292 & -0.230 & -0.317 & -0.140 & -0.254 & 0.019 \\
\hline & $(3.79)^{* *}$ & $(2.50)^{*}$ & $(1.61)$ & $(1.12)$ & $(1.87)$ & $(0.04)$ \\
\hline Two children (>1) & -0.509 & -0.434 & -0.773 & -0.227 & -0.297 & 0.081 \\
\hline & $(5.81)^{* *}$ & $(4.56)^{* *}$ & $(3.35)^{* *}$ & $(1.49)$ & $(1.76)$ & $(0.16)$ \\
\hline Three children $(<1,>1,>1)$ & -0.406 & -0.446 & -0.646 & -0.261 & -0.418 & -0.130 \\
\hline & $(2.87)^{* *}$ & $(2.40)^{*}$ & $(2.08)^{*}$ & $(1.29)$ & $(1.96)$ & $(0.22)$ \\
\hline Three older $(>1)$ children or more & -0.542 & -0.402 & -0.618 & -0.410 & -0.404 & -0.483 \\
\hline & $(3.53)^{* *}$ & $(2.04)^{*}$ & $(1.79)$ & $(1.66)$ & $(1.84)$ & $(0.56)$ \\
\hline Observations & 7357 & 5237 & 1105 & 5249 & 3410 & 1011 \\
\hline Number of id & 2281 & 1541 & 428 & 1875 & 1180 & 419 \\
\hline
\end{tabular}

Notes:

Fixed effects linear regressions.

Controls include Education, positive education difference, negative education difference, age, positive age difference (>3), negative age difference (>3), part time work status, full time work status, spouse working part time work, spouse working full time work, log of hourly wage, log of spouse's annual income and a constant.

$*$ : significant at $5 \%, * *$ : significant at $1 \%$ 
Table 5: Children and spousal love, by marital status

\begin{tabular}{|l|l|l|l|l|}
\hline & \multicolumn{2}{|c|}{ Women } & \multicolumn{2}{c|}{ Men } \\
\hline & Married & Cohabiting & Married & Cohabiting \\
\hline One child $(<1)$ & -0.046 & -0.106 & -0.080 & -0.160 \\
\hline & $(0.83)$ & $(1.07)$ & $(1.00)$ & $(1.26)$ \\
\hline One child (>1) & -0.177 & -0.485 & -0.302 & -0.375 \\
\hline & $(2.33)^{*}$ & $(3.69)^{* *}$ & $(2.87)^{* *}$ & $(2.28)^{*}$ \\
\hline Two children $(<1,>1)$ & -0.166 & -0.398 & -0.140 & -0.112 \\
\hline & $(1.58)$ & $(2.63)^{* *}$ & $(1.13)$ & $(0.45)$ \\
\hline Two children $(>1)$ & -0.351 & -0.681 & -0.215 & -0.199 \\
\hline & $(3.03)^{* *}$ & $(4.07)^{* *}$ & $(1.34)$ & $(0.72)$ \\
\hline Three children $(<1,>1,>1)$ & -0.156 & -0.701 & -0.200 & -0.171 \\
\hline & $(0.86)$ & $(2.31)^{*}$ & $(0.98)$ & $(0.42)$ \\
\hline Three older $(>1)$ children or more & -0.389 & -0.641 & -0.268 & -0.430 \\
\hline & $(1.79)$ & $(2.22)^{*}$ & $(1.21)$ & $(0.76)$ \\
\hline Observations & 3841 & 3516 & 2478 & 2771 \\
\hline Number of id & 1168 & 1537 & 857 & 1295 \\
\hline
\end{tabular}

Notes:

FE linear regressions.

Controls include Education, positive education difference, negative education difference, age, positive age difference ( $>3$ ), negative age difference $(>3)$, part time work status, full time work status, spouse working part time work, spouse working full time work, log of hourly wage, log of spouse's annual income and a constant.

$*$ : significant at $5 \%, * *$ : significant at $1 \%$ 
Table 6: Child ren and spousal love, by religion

\begin{tabular}{|l|l|l|l|l|l|l|}
\hline & \multicolumn{3}{|c|}{ Women } & \multicolumn{3}{c|}{ Men } \\
\hline & Catholic & Protestant & No religion & Catholic & Protestant & No religion \\
\hline One child (<1) & -0.166 & -0.046 & 0.048 & -0.150 & -0.118 & 0.063 \\
\hline & $(1.97)^{*}$ & $(0.73)$ & $(0.25)$ & $(1.45)$ & $(1.22)$ & $(0.30)$ \\
\hline One child (>1) & -0.248 & -0.358 & -0.311 & -0.392 & -0.295 & -0.484 \\
\hline Two children $(<1,>1)$ & $(2.40)^{*}$ & $(4.15)^{* *}$ & $(1.20)$ & $(2.87)^{* *}$ & $(2.24)^{*}$ & $(1.78)$ \\
\hline & -0.282 & -0.267 & -0.308 & -0.087 & -0.009 & -1.014 \\
\hline Two children (>1) & $(1.91)$ & $(2.52)^{*}$ & $(1.31)$ & $(0.60)$ & $(0.06)$ & $(1.84)$ \\
\hline & -0.431 & -0.501 & -0.728 & -0.326 & -0.132 & -0.544 \\
\hline Three children & $(2.94)^{* *}$ & $(4.38)^{* *}$ & $(1.90)$ & $(1.42)$ & $(0.58)$ & $(1.31)$ \\
\hline$(<1,>1,>1)$ & -0.032 & -0.440 & -0.900 & -0.192 & -0.224 & -0.550 \\
\hline Three older $(>1)$ children & $(0.14)$ & $(2.17)^{*}$ & $(2.19)^{*}$ & $(0.36)$ & $(0.93)$ & $(0.86)$ \\
\hline or more & -0.580 & -0.525 & -0.192 & -0.328 & -0.315 & -1.124 \\
\hline Observations & $(1.92)$ & $(2.53)^{*}$ & $(0.48)$ & $(0.96)$ & $(1.17)$ & $(0.84)$ \\
\hline Number of id & 1998 & 4171 & 828 & 1398 & 2861 & 734 \\
\hline
\end{tabular}

Notes:

FE linear regressions.

Controls include Education, positive education difference, negative education difference, age, positive age difference (>3), negative age difference (>3), part time work status, full time work status, spouse working part time work, spouse working full time work, log of hourly wage, log of spouse's annual income and a constant.

$*$ : significant at $5 \%, * *$ : significant at $1 \%$ 
Table 7: Children and spousal love, by religiosity

\begin{tabular}{|l|l|l|l|l|}
\hline & \multicolumn{2}{|c|}{ Women } & \multicolumn{2}{c|}{ Men } \\
\hline & Religious & Not Religious & Religious & Not Religious \\
\hline One child (<1) & -0.049 & -0.072 & -0.058 & -0.134 \\
\hline & $(0.63)$ & $(1.19)$ & $(0.58)$ & $(1.36)$ \\
\hline One child (>1) & -0.377 & -0.267 & -0.198 & -0.391 \\
\hline & $(3.27)^{* *}$ & $(3.63)^{* *}$ & $(1.35)$ & $(3.26)^{* *}$ \\
\hline Two children & -0.436 & -0.189 & 0.088 & -0.330 \\
\hline$(<1,>1)$ & $(2.97)^{* *}$ & $(2.10)^{*}$ & $(0.43)$ & $(1.92)$ \\
\hline Two children & -0.571 & -0.429 & 0.043 & -0.381 \\
\hline$(>1)$ & $(3.60)^{* *}$ & $(4.34)^{* *}$ & $(0.16)$ & $(1.98)^{*}$ \\
\hline Three children & -0.746 & -0.115 & -0.078 & -0.560 \\
\hline$(<1,>1,>1)$ & $(2.73)^{* *}$ & $(0.77)$ & $(0.26)$ & $(1.86)$ \\
\hline Three older $(>1)$ & -0.785 & -0.335 & 0.031 & -0.895 \\
\hline children or more & $(2.95)^{* *}$ & $(1.63)$ & $(0.10)$ & $(2.02)^{*}$ \\
\hline Observations & 2443 & 4494 & 1938 & 2914 \\
\hline Number of id & 743 & 1365 & 675 & 1034 \\
\hline
\end{tabular}

Notes:

FE linear regressions.

Controls include Education, positive education difference, negative education difference, age, positive age difference (>3), negative age difference (>3), part time work status, full time work status, spouse working part time work, spouse working full time work, log of hourly wage, log of spouse's annual income and a constant.

$*$ : significant at 5\%,**: significant at $1 \%$ 


\section{Appendix A1: Predicted probability that respondents feel they receive maximum love from spouse (i.e. spousal love $=10$ ).}

\begin{tabular}{|l|l|l|l|l|l|l|}
\hline & \multicolumn{3}{|c|}{ Women } & \multicolumn{3}{c|}{ Men } \\
\hline Children & Yes & No kid & Diff & Yes & No kid & Diff \\
\hline One child $(<1)$ & 0.815 & 0.812 & $-0.003^{*}$ & 0.759 & 0.748 & $0.010^{* *}$ \\
\hline One child $(>1)$ & 0.714 & 0.812 & $-0.098^{* *}$ & 0.687 & 0.748 & $-0.060^{* *}$ \\
\hline Two children $(<1,>1)$ & 0.773 & 0.812 & $-0.038^{* *}$ & 0.743 & 0.748 & -0.005 \\
\hline Two children $(>1)$ & 0.666 & 0.812 & $-0.144^{* *}$ & 0.645 & 0.748 & $-0.102^{* *}$ \\
\hline Three children $(<1,>1,>1)$ & 0.780 & 0.812 & $-0.031^{* *}$ & 0.675 & 0.748 & $-0.072^{* *}$ \\
\hline $\begin{array}{l}\text { Three older }(>1) \text { children or } \\
\text { more }\end{array}$ & 0.731 & 0.812 & $-0.080^{* *}$ & 0.684 & 0.748 & $-0.063^{* *}$ \\
\hline
\end{tabular}

Note: Controls include Education, positive education difference, negative education difference, age, positive age difference ( $>3$ ), negative age difference $(>3)$, part time work status, full time work status, spouse working part time work, spouse working full time work, log of hourly wage, log of spouse's annual income and a constant. This regression does not include individual fixed effects.

$*$ : significant at $5 \%, * *$ : significant at $1 \%$ 